\title{
The health-related determinants of eating pattern of high school athletes in Goiás, Brazil
}

\author{
Matias Noll ${ }^{1,2^{*}}$, Ana Paula Santos Rodrigues ${ }^{2}$ and Erika Aparecida Silveira ${ }^{2}$
}

\begin{abstract}
Background: Athletes put their health at short- and long-term risk and a detailed investigation of health outcomes is important because it should allow the development of more specific interventions. This study aimed to evaluate the health-related determinants of eating pattern of high school athletes.

Methods: The study enrolled 248 Brazilian athletes aged 14-20 years. Eating pattern outcomes included skipping breakfast, vegetable and fruit consumption, and sweets consumption. The following factors were considered as independent variables: sociodemographic, economic, anthropometry, body weight control, psychosocial, sedentary behavior, sleeping time, meals, alcohol and smoking, and strength variables. Data were analyzed using Poisson regression model and the effect measure was the prevalence ratio (PR).

Results: The results showed that $45.6 \%$ of the athletes skipped breakfast, $29.8 \%$ ate sweets regularly, and only $8.9 \%$ consumed vegetables and fruit regularly. Multiple analysis revealed the following positive associations: breakfast skipping and vomiting or using laxatives to lose weight (PR, 1.12; 95\% Cl, 1.01-1.26); low fruit and vegetable consumption and using pills to lose weight (PR, 1.05; 95\% Cl, 1.02-1.07); high sweets consumption and female athletes (PR, 1.32; 95\% Cl, 1.12-1.55); high sweets consumption and more than $2 \mathrm{~h}$ spent watching TV (PR, 1.19; 95\% Cl, 1.02-1.39).
\end{abstract}

Conclusions: Our findings indicated that sociodemographic, body weight control and sedentary factors are determinants on eating patterns of high school athletes.

Keywords: Adolescent, Sport, Health, Eating behavior, Food

\section{Background}

Engaging in sports is an important way to reduce a sedentary lifestyle, increase physical activity levels, and promote healthy habits [1]. Active people are at lower risk for many health-related conditions such as cardiovascular disease, diabetes, obesity, cancer, poor skeletal health, poor quality of life, and mental health [2,3]. Therefore, sports participation is stimulated, both within and outside the school environment. Recent mega events in Brazil such as the 2014 FIFA World Cup, 2015 Pan American Games, and 2016 Olympic and Paralympic Games, may have generated considerable interest in sporting activities and possibly encouraged exercising in the young population.

\footnotetext{
* Correspondence: matiasnoll@yahoo.com.br

${ }^{1}$ Instituto Federal Goiano - Campus Ceres, Ceres, Brazil

²Programa de Pós-Graduação em Ciências da Saúde, Faculdade de Medicina,

Universidade Federal de Goiás, Goiânia, Brazil
}

Moreover, programs developed by the Brazilian Ministry of Sports, such as the Programa Segundo Tempo ("Second Half Program"), have provided access to sports practice for more than 4 million adolescents [4].

Despite the health benefits of sports participation, it poses risks for young athletes [1] such as alcohol consumption, smoking, vomiting or using laxatives, taking weight-loss pills, and using performance-enhancing substances [5-7]. These behaviors may considerably preclude the chances of sporting success and reduce both career longevity and health in adulthood [8]. Moreover, the eating pattern is one of the factors that have received attention because of its relationship with sports performance. Thus, the same attention given to increase sport participation should be given to the health of young athletes as well to the risks brought about by sports.

(c) The Author(s). 2020 Open Access This article is distributed under the terms of the Creative Commons Attribution 4.0 International License (http://creativecommons.org/licenses/by/4.0/), which permits unrestricted use, distribution, and reproduction in any medium, provided you give appropriate credit to the original author(s) and the source, provide a link to the Creative Commons license, and indicate if changes were made. The Creative Commons Public Domain Dedication waiver (http://creativecommons.org/publicdomain/zero/1.0/) applies to the data made available in this article, unless otherwise stated. 
Scaglioni et al. [9] described that the eating pattern involves a complex interaction of genetic, familial, and environmental factors. Although the relationship between eating patterns and health has been underestimated, and most guidelines treat foods as mere nutrient carriers [10-12], current investigations have extended beyond the simple intake of nutrients to consider food choice as well as its level of processing [13, 14]. However, recent systematic review with young athletes [15] showed that most studies still focus on nutrient analysis and there is a gap regarding eating patterns studies and its associate factors. Recent study [16] found that young athletes who practice sports for many years have a more regular healthy food consumption. Nevertheless, the relationship between health outcomes and eating patterns was underestimated [12, 15].

It is necessary to monitor the eating patterns of young athletes since their attitudes to meals and food choice can impact their training and performance, as well as their optimal growth and development [17]. Currently, skipping breakfast, fruit and vegetable consumption, and sweets consumption are key determinants of a healthy diet, and health factors related to these outcomes have been investigated $[17,18]$. Moreover, the health-related determinants of eating pattern of young athletes have not been well studied in emerging countries [15].

Athletes put their health at short- and long-term risk [5] and a detailed investigation of health outcomes is important because it should allow the development of more specific interventions. Thus, our study aimed to evaluate the health-related determinants of eating pattern in Brazilian high school athletes. We improved the assessment of health-related determinants, i.e. to evaluate common outcomes such as anthropometry, sedentary behavior, alcohol consumption, and smoking; and also included poorly assessed factors such as psychosocial factors, body weight control, and trunk and handgrip strength.

\section{Methods}

The present cross-sectional study was based on data from the 'Brazilian High School Athlete Study: Health-related Outcomes', a study performed during the state phase of the 2015 Federal Institutes Games (FIGs) in Brazil [16, 19, 20]. These games are organized annually and the state phase, in which the top-ranked athletes are selected, is followed by the regional and national phases. In 2015, the FIGs occurred in the Urutaí city, state of Goiás, Brazil.

Representing 12 cities of the state of Goiás in the Brazilian Midwest, a total of 361 high school athletes regularly enrolled in the Federal Institute participated in the FIG. Athletes were included based on the following inclusion criteria: age of 14-20 years, no previous history of musculoskeletal surgery, and participation in one of the following sports - handball, basketball, volleyball, or soccer. Pregnancy, injured athletes, as well as those who declined to participated were excluded from the study.

Athletes were invited to participate by contacting coaches 1 week before the tests as well as by posters fixed in the competitive environment. All athletes participating in the FIGs were recruited to the present study, and 320 athletes were included. Twenty-seven athletes were injured and 42 declined to participate, thus, the study enrolled 251 athletes. All tests and questionnaires were performed individually in a properly equipped room near the competition environment.

An overview of the measures, classification parameters, and dichotomization, used in this study, are presented in the Additional file 1: Table S1. The Brazilian National School-Based Health Survey (PeNSE), a reproducible selfadministered questionnaire [21], which was validated using 24-h recall, was used to assess the following variables: sociodemographic, economic, body weight control, psychosocial, and alcohol consumption and smoking.

The PeNSE was also used to evaluate the frequency of eating, within the previous 7 days, of vegetable, fruits, and sweets, and how often the athlete had breakfast. These variables were evaluated using the following questions: "In the last 7 days, on how many days did you eat at least one type of raw or cooked vegetable?", "In the last 7 days, on how many days did you eat fresh fruits or fruits salad?", "In the last 7 days, on how many days did you eat sweets?", and "In the last 7 days, on how many days did you have breakfast?". The eight available response options were "I did not eat in the last 7 days," "I ate on 1 day $(2, \ldots$, 6 days) of the last 7 days," and "I ate on all of the last 7 days" [21]. For data analysis purposes, they were categorized as regularly consumed (for at least 5 days in the previous 7 days) or not [22-26]. All athletes are regularly enrolled in school and study in the mornings, so we consider breakfast between 6 and 8:59 am [27]. At the weekend it was considered the same time for breakfast.

At the outset of the study, the researcher explained to the subjects in a group meeting how the questionnaire should be answered. The subjects then answered the questionnaires individually. The PeNSE reliability was tested on 34 high school students by the 7-day testretest protocol. All the questions indicated good and very good values (Kappa range, 0.701-0.841) [16].

The short version of the International Physical Activity Questionnaire (IPAQ) validated for the Brazilian population was used to evaluate sedentary behavior [28]. Sedentary behavior was assessed using the short-IPAQ sitting item that consisted of a single question regarding the time spent on activities such as studying, reading, watching television (TV), computer use, and other sitting or reclining activities in a weekday and at weekends. Excessive sitting time was classified as sitting time $\geq 9 \mathrm{~h}$ daily. This threshold was consistent with the highest quintile of IPAQ- 
assessed sitting time in the 20-country comparison of the descriptive epidemiology of sitting. Moreover, to determine the time spent sleeping, watching television, and using computers, a self-administered questionnaire entitled "Back Pain and Body Posture Evaluation Instrument" (BackPEI) was used [29].

Each athlete's body mass and height were measured. Students were wearing light clothes at the time of data collection and were instructed to remain standing, upright, with the face directed forward, and shoulders relaxed. For height and body weight measurement, we used a stadiometer (accuracy, $0.1 \mathrm{~mm}$ ) and a digital scale (Plenna-MEA-03140, São Paulo, Brazil; maximum capacity, $150 \mathrm{~kg}$; accuracy, $100 \mathrm{~g}$ ), respectively. Body mass index (BMI) in $\mathrm{kg} / \mathrm{m}^{2}$ was calculated by dividing the mass $(\mathrm{kg})$ by the squared height $\left(\mathrm{m}^{2}\right)$.

Handgrip strength was measured with the athlete sitting, elbow flexed at $90^{\circ}$, shoulders adducted and neutrally rotated, forearm in the neutral position, and the wrist $10^{\circ}$ extended [30]. Trunk strength was measured with the athlete standing, legs kept straight and the back flexed $45^{\circ}$. Each athlete performed two isometric valid trials $(5 \mathrm{~s})$ for the trunk and right and left-hand strength, with a 60-s rest period between trials, and the largest value was registered. The average of both handgrip strengths was considered. Trunk and handgrip strength were normalized by body weight.

For both strength tests, participants were encouraged to apply their maximum strength. Handgrip strength was evaluated using a hand dynamometer (EMG SYSTEM, TRF_MAN200 model, São José dos Campos, Brazil), and the trunk strength by a lumbar dynamometer (EMG System, TRF_ELMB200 model, São José dos Campos, Brazil). The dynamometers (nominal capacity $200 \mathrm{~kg}$, sensitivity 2 $\mathrm{mV} / \mathrm{V} \pm 10 \%$, error $<0.03 \%$, input resistance $405 \Omega$, output resistance $350 \Omega$ ) were calibrated before data collection and were adjusted according to the size of each athlete.

The test-retest reliability of the questionnaires and strength tests were good as shown in our previous study [20]. The present study was in accordance with the Helsinki Declaration and was approved by the Ethics Committee for Human Research of the Instituto Federal Goiano. Athletes and their parents or guardians, in the case of minors, voluntarily signed the informed consent form.

Data were analyzed using descriptive statistics and the Wald Chi-Square test of association (bivariate analysis) for the eating pattern outcomes: skip breakfast, irregular vegetable and fruit consumption, and regular sweet consumption. The following factors were considered independent group variables: sociodemographic, economic, anthropometry, body weight control, psychosocial, sedentary behavior, sleeping time, meals, alcohol and smoking, and strength variables. These variables are shown in the Additional file 1: Table S1.
Independent variables with a level of significance of $p<$ 0.20 in the bivariate analysis were included in a multiple analysis using the Poisson regression model with robust variance. The effect measure was the prevalence ratio (PR) with its respective $95 \%$ confidence intervals (CIs), and the reference category was selected to verify negative factors. We adjusted these analyses for sociodemographic (gender and age) variables $(\alpha=0.05)$. Statistical analyses were performed using the Statistical Package for the Social Sciences (SPSS 20.0, IBM, Armonk, NY, USA).

\section{Results}

Of the 251 athletes enrolled, 248 (98.8\%) completed the protocol. Of these, 144 (58.1\%) were aged 14-16 years and 104 (41.9\%) aged $17-20$ years, and most were boys (68.5\%).

The prevalence of outcomes is presented in Fig. 1. Of all the athletes, 54.5, 29.8, and 8.9\% had breakfast, ate sweets, and consumed vegetables and fruit regularly, respectively.

The high prevalence of athletes that felt lonely and lost sleep because of a concern, engaged in sedentary behavior, whose time sleeping per night was less than recommended, and who were involved with alcohol consumption and passive smoking, may be noted in Table 1.

Bivariate analysis examining the relationship between eating habits and health-related determinants are presented in the Table 2. These variables and others with $p<0.20$ were included in the multiple model.

After inserting the variables in the multiple analysis, our major findings indicated the following associations: (a) skipping breakfast was associated with vomiting or using laxatives to lose weight; (b) irregular fruit and vegetable consumption with using pills to lose weight; (c) regular sweets consumption with female athletes and with hours spent watching TV (Table 3).

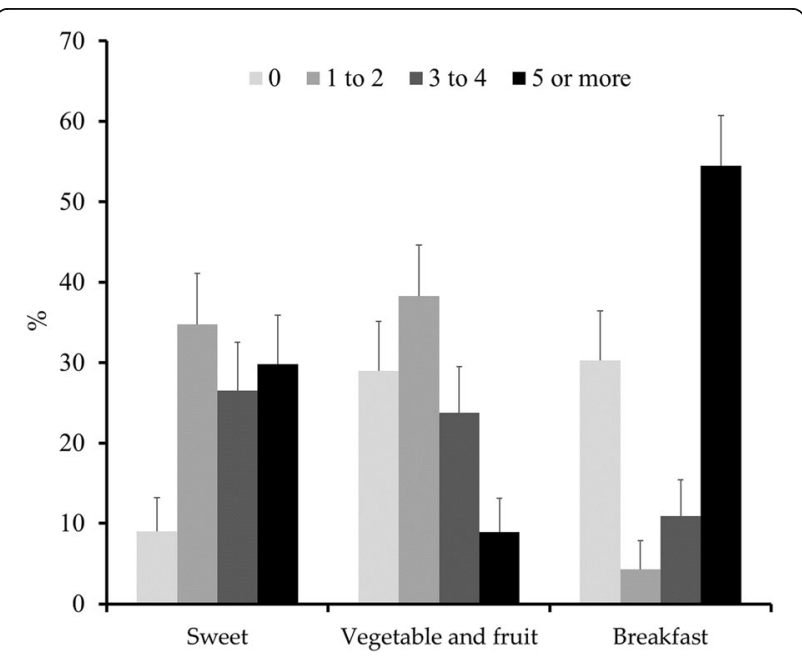

Fig. 1 Prevalence of eating pattern outcomes per week 
Table 1 Prevalence of health-related determinants

\begin{tabular}{|c|c|c|c|c|}
\hline Variables & Total N (\%) & Skip breakfast ${ }^{\mathrm{a}} \mathrm{n}(\%)$ & $\begin{array}{l}\text { Low vegetable and } \\
\text { fruit consumption }{ }^{a} \mathrm{n}(\%)\end{array}$ & $\begin{array}{l}\text { High sweets } \\
\text { consumption }{ }^{\mathrm{b}} \mathrm{n}(\%)\end{array}$ \\
\hline \multicolumn{5}{|l|}{ Sociodemographic } \\
\hline \multicolumn{5}{|l|}{ Age } \\
\hline $14-16$ years & $144(58.1)$ & $62(43.1)$ & 136(94.4) & 43(30.3) \\
\hline $17-20$ years & 104(41.9) & $51(49)$ & $90(85.6)$ & $30(29.1)$ \\
\hline \multicolumn{5}{|l|}{ Sex } \\
\hline Male & $170(68.5)$ & 79(46.5) & 158(92.9) & $34(20.2)$ \\
\hline Female & $78(31.5)$ & $34(43.6)$ & 68(87.2) & 39(50.6) \\
\hline \multicolumn{5}{|l|}{ Economic } \\
\hline \multicolumn{5}{|l|}{ Mother education level } \\
\hline Basic education & $53(23.1)$ & 23(43.4) & 47(88.7) & 16(30.2) \\
\hline High school/College & 176(76.9) & $82(46.6)$ & 163(92.6) & 49(28.3) \\
\hline \multicolumn{5}{|l|}{ Have a part time job } \\
\hline No & 219(88.7) & $98(44.7)$ & 199(90.9) & $67(31)$ \\
\hline Yes & 28(11.3) & $14(50)$ & 26(92.9) & $6(21.4)$ \\
\hline \multicolumn{5}{|l|}{ Anthropometric } \\
\hline \multicolumn{5}{|l|}{ Body mass index } \\
\hline Normal & $180(73.5)$ & $82(45.6)$ & 162(90) & 55(30.6) \\
\hline Overweight & $65(26.5)$ & $30(46.2)$ & 61(93.8) & 18(29) \\
\hline \multicolumn{5}{|l|}{ Body weight control } \\
\hline \multicolumn{5}{|c|}{ Vomiting or using laxatives to lose weight } \\
\hline No & 220(95.2) & $99(45)$ & 199(90.5) & $65(30)$ \\
\hline Yes & $11(4.8)$ & $7(63.6)$ & 10(90.9) & $6(54.4)$ \\
\hline \multicolumn{5}{|l|}{ Using pills to lose weight } \\
\hline No & 227(96.6) & 105(46.3) & 205(90.3) & $70(31.2)$ \\
\hline Yes & $8(3.4)$ & $3(37.5)$ & $8(100)$ & $2(25)$ \\
\hline \multicolumn{5}{|c|}{ Using pills to improve muscle mass } \\
\hline No & 217(92.3) & $100(46.1)$ & 196(90.3) & $69(32.2)$ \\
\hline Yes & $18(7.7)$ & $8(44.4)$ & 17(94.4) & $3(16.7)$ \\
\hline \multicolumn{5}{|l|}{ Psychosocial } \\
\hline \multicolumn{5}{|c|}{ Body weight self-perception } \\
\hline Normal & 130(55.6) & $61(46.9)$ & 113(86.9) & $40(31)$ \\
\hline Not normal & 104(44.4) & $47(45.2)$ & 99(95.2) & $32(31.4)$ \\
\hline \multicolumn{5}{|l|}{ Felt lonely last year } \\
\hline Never and Rarely & 162(68.9) & $72(44.4)$ & 146(90.1) & $50(31.4)$ \\
\hline Sometimes or more & $73(31.1)$ & $36(49.3)$ & 67(91.8) & 22(30.1) \\
\hline \multicolumn{5}{|c|}{ Lost sleep because of a concern last year } \\
\hline Never and Rarely & 171(73.1) & 79(46.2) & 154(90.1) & $44(26.2)$ \\
\hline Sometimes or more & 63(26.9) & 28(44.4) & 58(92.1) & 27(42.9) \\
\hline \multicolumn{5}{|c|}{ Felt intimidated last month } \\
\hline Never and Rarely & 199(82.6) & $89(44.7)$ & 191(91) & 59(30.1) \\
\hline Sometimes or more & $42(17.4)$ & $22(52.4)$ & $38(90.5)$ & 14(33.3) \\
\hline \multicolumn{5}{|l|}{ Sedentary Behavior } \\
\hline Time spent watching $T$ & & & & \\
\hline
\end{tabular}


Table 1 Prevalence of health-related determinants (Continued)

\begin{tabular}{|c|c|c|c|c|}
\hline Variables & Total N (\%) & Skip breakfast ${ }^{\mathrm{a}} \mathrm{n}(\%)$ & $\begin{array}{l}\text { Low vegetable and } \\
\text { fruit consumption }{ }^{\mathrm{a}} \mathrm{n}(\%)\end{array}$ & $\begin{array}{l}\text { High sweets } \\
\text { consumption }{ }^{\mathrm{b}} \mathrm{n}(\%)\end{array}$ \\
\hline 0-1 h per day & $143(62.2)$ & $65(45.5)$ & $127(88.8)$ & $32(22.5)$ \\
\hline$\geq 2 \mathrm{~h}$ per day & $87(37.8)$ & $41(47.1)$ & $82(94.3)$ & $32(37.6)$ \\
\hline \multicolumn{5}{|l|}{ Time spent using computer } \\
\hline 0-1 h per day & 105(49.8) & $40(38.1)$ & 98(93.3) & $27(26.2)$ \\
\hline$\geq 2 \mathrm{~h}$ per day & $106(50.2)$ & $53(50)$ & 96(90.6) & $32(30.2)$ \\
\hline \multicolumn{5}{|l|}{ Sitting time on a weekday } \\
\hline 0-8 h per day & 142(59.9) & $66(46.5)$ & 131(92.3) & $38(27.3)$ \\
\hline$\geq 9$ h per day & 95(40.1) & $42(44.2)$ & $86(90.5)$ & 34(35.8) \\
\hline \multicolumn{5}{|c|}{ Sitting time on a weekend day } \\
\hline 0-8 h per day & 99(42.1) & $72(43.6)$ & 150(90.9) & $52(32.1)$ \\
\hline$\geq 9$ h per day & 136(57.9) & $34(48.6)$ & 65(92.9) & 19(27.1) \\
\hline \multicolumn{5}{|l|}{ Meals } \\
\hline \multicolumn{5}{|l|}{ Have regular breakfast } \\
\hline No & 113(45.6) & - & 104(92) & 37(33.3) \\
\hline Yes & 135(54.4) & - & 122(90.4) & $36(26.9)$ \\
\hline \multicolumn{5}{|c|}{ Habit of eating in front of the TV } \\
\hline No & $98(39.5)$ & $44(44.9)$ & $86(87.8)$ & $21(21.6)$ \\
\hline Yes & $150(60.5)$ & $69(46)$ & 140(93.3) & $52(35.1)$ \\
\hline \multicolumn{5}{|l|}{ Sleeping time } \\
\hline \multicolumn{5}{|l|}{ Time sleeping per night } \\
\hline$\leq 7 \mathrm{~h}$ & $163(72.4)$ & $79(48.5)$ & 151(92.6) & $47(29.4)$ \\
\hline$\geq 8 \mathrm{~h}$ (Recommended) & $62(27.6)$ & $22(35.5)$ & $56(90.3)$ & 21(33.9) \\
\hline \multicolumn{5}{|l|}{ Alcohol and smoking } \\
\hline \multicolumn{5}{|c|}{ Alcohol consumption last month } \\
\hline No & 169(68.1) & $73(43.2)$ & 152(89.9) & $46(27.7)$ \\
\hline Yes & 79(31.9) & 40(50.6) & 74(93.7) & 27(34.2) \\
\hline \multicolumn{5}{|c|}{ Frequency of alcohol consumption ${ }^{c}$} \\
\hline 1 to 5 days last month & $51(64.6)$ & 27(52.9) & 48(94.1) & 16(31.4) \\
\hline$\geq 6$ days last month & 28(35.4) & 13(46.4) & 26(92.9) & 11(39.3) \\
\hline \multicolumn{5}{|c|}{ Doses of alcohol consumption on any occasion } \\
\hline 1 to 3 doses a time & $47(60.3)$ & 24(51.1) & 45(95.7) & 15(31.9) \\
\hline$\geq 4$ doses a time & $31(39.7)$ & 15(48.4) & 28(90.3) & 12(38.7) \\
\hline \multicolumn{5}{|l|}{ Smoking habits last month } \\
\hline No & 233(94) & 104(44.6) & 213(91.4) & 70(30.4) \\
\hline Yes & $15(6)$ & $9(60)$ & 13(86.7) & $3(20)$ \\
\hline \multicolumn{5}{|l|}{ Passive smoking last week } \\
\hline No & $102(42.5)$ & $45(44.1)$ & $94(92.2)$ & $25(25)$ \\
\hline Yes & $138(57.5)$ & $67(48.6)$ & 124(89.9) & $47(34.3)$ \\
\hline \multicolumn{5}{|l|}{ Smoking parents } \\
\hline No & 189(79.4) & $87(46)$ & 173(91.5) & $54(29)$ \\
\hline Yes & 49(20.6) & 24(49) & 43(87.8) & 17(34.7) \\
\hline \multicolumn{5}{|l|}{ Strength } \\
\hline Trunk strength ${ }^{d}$ & & & & \\
\hline
\end{tabular}


Table 1 Prevalence of health-related determinants (Continued)

\begin{tabular}{|c|c|c|c|c|}
\hline Variables & Total N (\%) & Skip breakfast ${ }^{a} \mathrm{n}(\%)$ & $\begin{array}{l}\text { Low vegetable and } \\
\text { fruit consumption }{ }^{\mathrm{a}} \mathrm{n}(\%)\end{array}$ & $\begin{array}{l}\text { High sweets } \\
\text { consumption }{ }^{\mathrm{b}} \mathrm{n}(\%)\end{array}$ \\
\hline Low $(1.27 \pm 0.27)$ & $123(50.2)$ & 54(43.9) & 109(88.6) & $34(27.9)$ \\
\hline High $(1.77 \pm 0.35)$ & $122(49.8)$ & $58(47.5)$ & 114(93.4) & $38(31.7)$ \\
\hline \multicolumn{5}{|l|}{ Handgrip strength ${ }^{d}$} \\
\hline Low $(0.45 \pm 0.08)$ & $123(50.2)$ & $55(44.7)$ & 109(88.6) & 45(36.9) \\
\hline High $(0.71 \pm 0.85)$ & $122(49.8)$ & $57(46.7)$ & $114(93.4)$ & $27(22.5)$ \\
\hline
\end{tabular}

${ }^{\mathrm{a}}$ Irregular consumption ( $<5$ days in the previous 7 days); ${ }^{\mathrm{b}}$ Regular consumption (at least 5 days in the previous 7 days)

c Only students that consumed alcohol last month; ${ }^{d}$ Normalized by body weight

\section{Discussion}

Our main results indicated the presence of unhealthy behaviors and inappropriate eating patterns in young Brazilian athletes. Moreover, health-related variables are significantly associated with eating pattern: skipping breakfast with vomiting or using laxatives to lose weight; lower fruit and vegetable consumption with using pills to lose weight; and high sweets consumption with two or more hours per day spent watching TV. In emerging countries, research about the effect of health-related determinants on eating pattern is still incipient, and this is the first study with Latin-American high school athletes in this respect [15], providing essential information for more interventions focused on improving unhealthy behaviors.

Our results indicated that approximately half of those assessed skipped breakfast. This prevalence is higher compared with that found in Brazilian adolescents (35\%) [31] and around the world (4 to 42\%) [32-38]. Recent studies have demonstrated that breakfast is an important meal and is related to several benefits, such as adequate nutrition intake, diet quality and improved exercise performance [35], general health (lower BMI, waist circumference, body fat percentage, and glucose levels) [39], and cognitive and academic performance [40]. Possible reasons for breakfast omission in adolescents athletes include lack of time, poor availability of foods and beverages, and the intention to create an energy deficit to help weight control [40-42]. Although dietary habits that focus on skipping breakfast lead to energy deficit, they may result in unhealthy habits like nibbling snack foods, mainly those high in sugar or fat, culminating in the inability to weight self-control [41].

Restricting nutritional intake in early sports career and weight loss behavior are not recommended and may result in eating disorders [43-45]. In agreement with our findings, a large cross-sectional study of adolescents in the United States demonstrated that vomiting or using laxatives to lose weight (approximately 6\%) was positively associated with skipping breakfast [32]. However, regular breakfast consumption is essential to improve performance and is related to the consumption of fiberrich products that may improve glucose and insulin metabolism, appetite regulation (hunger and satiety), energy balance, and weight control [18]. This implies that regular breakfast helps achieve an ideal body shape and may preclude weight loss behavior.

Our results show that only one-tenth of all athletes regularly consumed vegetables and fruit. These values are much lower than indicated in the literature [33, 46-48]. A study with American adolescent participants in sports [49] found a regular consumption of fruits and vegetables in approximately $50 \%$ of young athletes. Currently, it is accepted that a diet rich in fruits and vegetables is associated with lower risks for diabetes, obesity, cardiovascular diseases, and cancer, and was found to be inversely associated with all-cause mortality [50-53]. Although concerning results are expected since Brazilian adolescents have shown unhealthy eating behaviors, with only $30 \%$ eating vegetables and fruit regularly [23], our findings indicated a greater problem.

Low vegetable and fruit consumption were associated with weight loss behavior. The present association may be a direct result of using a weight loss medication that suppresses the appetite as well as a non-direct relationship because athletes may want to achieve weight loss by reducing overall energy intake via fruit and vegetable intake restriction. In contrast, results from American youths involved in sports did not show an association between pills intake and fruit and vegetable consumption, but this may be because they were not competitive athletes [54]. Concern is required regarding pills use without prescription to achieve weight loss, because it leads to decreased vegetable and fruit ingestion, and may consequently result in nutrient deficiencies and other adverse health effects, such as eating disorders [17].

Our results show that approximately one-third of all athletes ate sweets regularly. Results from Brazilian athlete [48] and non-athlete youths [22] demonstrated a similar prevalence $(25-40 \%)$ of regular sweet consumption. Reducing sugar ingestion is essential for health [55], because of the strong association between cardiovascular disease and type 2 diabetes mellitus [56-59]. This is a serious concern because of the characteristics of ultra-processed foods (high energy density, free sugar, sodium, total fat and saturated fat; low protein, and fiber) [60,61]. Recent studies $[13,62]$ and the Brazilian Dietary Guidelines [63] advocate for the restriction of foods and beverages with low 
Table 2 Association of eating pattern with sociodemographic, economic, anthropometric, body weight control, psychosocial factors, sedentary time, meals, sleeping time, alcohol and smoke, and handgrip strength variables

\begin{tabular}{|c|c|c|c|c|c|c|}
\hline & \multicolumn{2}{|l|}{ Skip breakfast ${ }^{a}$} & \multicolumn{2}{|c|}{$\begin{array}{l}\text { Low vegetable and } \\
\text { fruit consumption }{ }^{\text {a }}\end{array}$} & \multicolumn{2}{|c|}{ High sweets consumption ${ }^{b}$} \\
\hline & PR $(95 \% \mathrm{Cl})$ & $p$ & $\mathrm{PR}(95 \% \mathrm{Cl})$ & $p$ & PR $(95 \%$ Cl) & $p$ \\
\hline \multicolumn{7}{|l|}{ Sociodemographic } \\
\hline Age $-14-16$ years & $0.98(0.93-1.03)$ & 0.350 & $1.03(1.01-1.05)$ & 0.042 & $1.01(0.88-1.17)$ & 0.845 \\
\hline Sex - female & $0.98(0.94-1.04)$ & 0.672 & $0.98(0.95-1.01)$ & 0.179 & $1.43(1.24-1.65)$ & 0.001 \\
\hline \multicolumn{7}{|l|}{ Economic } \\
\hline Mother education level - basic education & $0.99(0.93-1.05)$ & 0.682 & $0.99(0.95-1.02)$ & 0.412 & $1.02(0.86-1.22)$ & 0.794 \\
\hline Have a part time job - yes & $1.02(0.94-1.10)$ & 0.598 & $1.01(0.97-1.04)$ & 0.704 & $0.88(0.70-1.10)$ & 0.275 \\
\hline \multicolumn{7}{|l|}{ Anthropometric } \\
\hline Body mass index - overweight & $1.01(0.95-1.06)$ & 0.934 & $1.01(0.99-1.04)$ & 0.301 & $0.98(0.83-1.16)$ & 0.821 \\
\hline \multicolumn{7}{|l|}{ Body weight control } \\
\hline Vomit or use of laxatives to lose weight - yes & $1.07(0.96-1.20)$ & 0.196 & $1.01(0.94-1.06)$ & 0.959 & $1.31(0.98-1.75)$ & 0.071 \\
\hline Pills used to lose weight - yes & $0.96(0.84-1.11)$ & 0.621 & $1.03(1.02-1.04)$ & 0.001 & $0.92(0.61-1.39)$ & 0.700 \\
\hline Pills used to improve muscle mass - yes & $0.99(0.90-1.09)$ & 0.893 & $1.01(0.98-1.05)$ & 0.472 & $0.81(0.62-1.06)$ & 0.126 \\
\hline \multicolumn{7}{|l|}{ Psychosocial } \\
\hline Body weight self-perception - not normal & $0.99(0.94-1.05)$ & 0.792 & $1.03(1.01-1.05)$ & 0.023 & $1.01(0.87-1.17)$ & 0.953 \\
\hline Felt lonely last year - sometimes or more & $1.02(0.96-1.08)$ & 0.487 & $1.01(0.98-1.03)$ & 0.677 & $0.98(0.84-1.15)$ & 0.841 \\
\hline Lost sleep last year - sometimes or more & $0.99(0.94-1.05)$ & 0.811 & $1.01(0.98-1.04)$ & 0.625 & $1.22(1.04-1.43)$ & 0.014 \\
\hline Felt intimidated last month - sometimes or more & $1.03(0.97-1.10)$ & 0.361 & $1.00(0.96-1.03)$ & 0.923 & $1.04(0.86-1.26)$ & 0.682 \\
\hline \multicolumn{7}{|l|}{ Sedentary time } \\
\hline Time spent watching TV per day $\geq 2 \mathrm{~h}$ & $1.01(0.95-1.06)$ & 0.805 & 1.02(0.99-1.04) & 0.134 & $1.21(1.04-1.40)$ & 0.014 \\
\hline Time spent using computer per day $\geq 2 \mathrm{~h}$ & $1.05(0.99-1.11)$ & 0.079 & $0.99(0.97-1.02)$ & 0.460 & $1.05(0.90-1.23)$ & 0.523 \\
\hline Sitting time at a weekday $\geq 9 \mathrm{~h}$ & $0.99(0.94-1.04)$ & 0.731 & $0.99(0.97-1.02)$ & 0.645 & $1.11(0.95-1.29)$ & 0.169 \\
\hline Sitting time at a weekend day $\geq 9 \mathrm{~h}$ & $1.02(0.96-1.08)$ & 0.486 & $1.01(0.98-1.03)$ & 0.608 & $0.94(0.80-1.10)$ & 0.448 \\
\hline \multicolumn{7}{|l|}{ Meals } \\
\hline Have regular breakfast - no & - & & $1.01(0.98-1.03)$ & 0.643 & $1.08(0.94-1.25)$ & 0.271 \\
\hline Habit of eating in front of the TV - yes & $1.01(0.93-1.09)$ & 0.865 & 1.02(0.99-1.05) & 0.153 & $1.18(1.03-1.37)$ & 0.020 \\
\hline \multicolumn{7}{|l|}{ Sleeping time } \\
\hline Time sleeping per night $\leq 7 \mathrm{~h}$ & $1.04(0.98-1.11)$ & 0.187 & $1.00(0.97-1.03)$ & 0.965 & $0.99(0.83-1.17)$ & 0.873 \\
\hline \multicolumn{7}{|l|}{ Alcohol and smoke } \\
\hline Alcohol consumption last month - yes & $1.03(0.98-1.09)$ & 0.271 & $1.01(0.99-1.04)$ & 0.298 & $1.08(0.93-1.26)$ & 0.303 \\
\hline Frequency of alcohol consumption last month - 6 or more & $0.97(0.89-1.07)$ & 0.580 & $0.99(0.96-1.04)$ & 0.830 & $1.10(0.85-1.42)$ & 0.477 \\
\hline Doses of alcohol on any occasion last month -4 or more & $0.99(0.90-1.08)$ & 0.817 & $0.98(0.94-1.02)$ & 0.374 & $1.08(0.84-1.39)$ & 0.536 \\
\hline Smoking habits last month - yes & $1.06(0.96-1.17)$ & 0.227 & $0.98(0.92-1.05)$ & 0.599 & $0.87(0.65-1.17)$ & 0.362 \\
\hline Passive smoking last week - yes & $1.02(0.97-1.07)$ & 0.496 & $0.99(0.97-1.02)$ & 0.534 & $1.12(0.97-1.30)$ & 0.120 \\
\hline Parents smoking habits - yes & $1.01(0.95-1.08)$ & 0.712 & $0.99(0.95-1.02)$ & 0.461 & $1.07(0.90-1.28)$ & 0.445 \\
\hline \multicolumn{7}{|l|}{ Strength } \\
\hline Trunk strength - low & $0.98(0.90-1.06)$ & 0.567 & $0.98(0.96-1.01)$ & 0.201 & $0.95(0.82-1.10)$ & 0.518 \\
\hline Handgrip strength - low & $0.99(0.94-1.04)$ & 0.753 & $0.98(0.96-1.01)$ & 0.185 & $1.20(1.04-1.38)$ & 0.013 \\
\hline
\end{tabular}

Bold $p$-values reflect statistical significance $(p<0.05)$. $P R$ Prevalence ratio; $95 \% \mathrm{Cl} 95 \%$ Confidence interval; ${ }^{\text {a }}$ Irregular consumption $(<5$ days in the previous 7 days); ${ }^{\mathrm{b}}$ Regular consumption (at least 5 days in the previous 7 days)

nutritional value and have recommended a new approach that considers the choice of foods and meals, and the level of processing foods undergo.
Sedentary behavior and the media have a considerable influence on eating patterns [64-67]. Our findings showed that athletes who spent more time watching TV ate more 
Table 3 Adjusted prevalence ratio for eating pattern and sociodemographic, body weight control, psychosocial, sedentary time, meals, sleeping time, alcohol and smoke, and strength variables

\begin{tabular}{|c|c|c|c|c|c|c|}
\hline & \multicolumn{2}{|l|}{ Skip breakfast ${ }^{a}$} & \multicolumn{2}{|c|}{$\begin{array}{l}\text { Low vegetable and fruit } \\
\text { consumption }{ }^{\text {a }}\end{array}$} & \multicolumn{2}{|c|}{ High sweets consumption ${ }^{b}$} \\
\hline & Adjusted PR (95\% Cl) & $p$ & Adjusted PR (95\% Cl) & $p$ & Adjusted PR (95\% Cl) & $p$ \\
\hline \multicolumn{7}{|l|}{ Sociodemographic } \\
\hline Age - 14-16 years & & & $1.03(1.00-1.05)$ & 0.059 & & \\
\hline Sex - female & & & $0.98(0.95-1.02)$ & 0.359 & $1.32(1.12-1.55)$ & 0.010 \\
\hline \multicolumn{7}{|l|}{ Body weight control } \\
\hline Vomit or use of laxatives to lose weight - yes & $1.12(1.01-1.26)$ & 0.036 & & & $1.10(0.88-1.39)$ & 0.390 \\
\hline Pills used to lose weight - yes & & & $1.05(1.02-1.07)$ & 0.001 & & \\
\hline Pills used to improve muscle mass - yes & & & & & $0.92(0.67-1.26)$ & 0.590 \\
\hline \multicolumn{7}{|l|}{ Psychosocial } \\
\hline Body weight self-perception - not normal & & & $1.02(0.99-1.05)$ & 0.067 & & \\
\hline Loss of sleep last year - sometimes or more & & & & & $1.11(0.94-1.32)$ & 0.195 \\
\hline \multicolumn{7}{|l|}{ Sedentary time } \\
\hline Time spent watching per day $\geq 2 \mathrm{~h}$ & & & 1.02(0.99-1.05) & 0.172 & $1.19(1.02-1.39)$ & 0.030 \\
\hline Time spent using computer per day $\geq 2 \mathrm{~h}$ & $1.05(0.99-1.11)$ & 0.106 & & & & \\
\hline Sitting time at a weekday $\geq 9 \mathrm{~h}$ & & & & & 1.04(0.88-1.22) & 0.623 \\
\hline \multicolumn{7}{|l|}{ Meals } \\
\hline Habit of eating in front of the TV - yes & & & $1.01(0.98-1.05)$ & 0.343 & 1.13(0.96-1.33) & 0.125 \\
\hline \multicolumn{7}{|l|}{ Sleeping time } \\
\hline Time sleeping per night $\leq 7 \mathrm{~h}$ & 1.05(0.99-1.13) & 0.099 & & & & \\
\hline \multicolumn{7}{|l|}{ Alcohol and smoke } \\
\hline Passive smoking last week - yes & & & & & $1.09(0.94-1.27)$ & 0.256 \\
\hline \multicolumn{7}{|l|}{ Strength } \\
\hline Handgrip strength - low & & & $0.99(0.96-1.02)$ & 0.469 & $1.00(0.84-1.19)$ & 0.760 \\
\hline
\end{tabular}

Multiple analysis according to the Poisson regression model with robust variance. Prevalence ratio (PR) was the effect measure with its respective $95 \%$ confidence intervals (Cls). The model was adjusted for sex and age including independent variables (with $p<0.20$ in the bivariate analysis). Bold $p$-values denote statistical significance $(p<0.05) ;{ }^{\text {a }}$ Irregular consumption ( $<5$ days in the previous 7 days); ${ }^{\text {b }}$ Regular consumption (at least 5 days in the previous 7 days)

sweets. Moreover, we demonstrated that girls were more likely to consume sweets compared with boys. A greater desire to consume sweets, soft drinks, and fast food may be due to several hours in front of the TV which exposes the viewer to more media advertisements and sedentary behavior that stimulate poor eating habits $[25,66]$. These two unhealthy behaviors are a source of greater concern because they are directly related to obesity and other unhealthy behaviors [68].

Although other health-related determinants were not associated with eating patterns, they are also points of concern. Regarding alcohol consumption, the prevalence is high probably because sports are often related with socializing outside the sporting environment and may be greatly influenced by social norms or the traditional relationship between alcohol and sport due to sports sponsorship by beer companies [69]. Decreased training performance due to dehydration and poor recovery may be a consequence of alcohol consumption [38]. On the other hand, smoking had a low prevalence in the present study, possibly because such habit is socially unacceptable [70], especially because in Brazil there was widespread governmental education and preventive programs in the last years. Other health-related behaviors had a high prevalence such as feeling lonely and losing sleep because of a concern, sedentary behavior, less sleeping time, and passive smoking.

Regarding the strengths of the study; first, poorly assessed outcomes such as psychosocial characteristics, body weight control, and handgrip strength were investigated. Second, the investigation of health-related outcomes and their association with eating pattern is essential because health professionals and coaches may be trained to conduct interventions targeted at these unhealthy behaviors. However, some limitations need to be listed: the questionnaire did not evaluate the amount of each food group consumed per day; and, since the food information was self-reported some results could be over or underestimate due to the selfassessment of each athlete and also memory bias. Although there is a consensus in the literature about the importance of implementing intervention programs for young athletes, 
there is still a lack of knowledge about the eating patterns and their association with health-related behavior. Therefore, our results reinforce the need for education programs improving eating patterns and unhealthy behaviors. These aspects are essential to this critical transition period from adolescence to adulthood.

\section{Conclusion}

High school athletes do not have adequate eating patterns and adequate health-related behavior. Sociodemographic, body weight control and sedentary time are determinant factors of the eating pattern. In addition to evaluating important health-related determinants (i.e. to evaluate common outcomes such as anthropometry, sedentary behavior, substance use); we also have included poorly assessed factors such as psychosocial factors, body weight control, and trunk and handgrip strength. This information is essential to conduct preventive interventions and for improving the sport performance that will benefit athletes throughout their life. Moreover, nutrition and health promotion programs should not only focus on the specific nutrients, but also on eating behavior. Future researches need to evaluate these patterns in longitudinal studies to understand cause and effect results.

\section{Supplementary information}

Supplementary information accompanies this paper at https://doi.org/10. 1186/s13690-020-0396-3.

Additional file 1 Table S1. Description of outcomes and determinants, and measures classification used in this study.

\section{Abbreviations \\ BackPEl: Back Pain and Body Posture Evaluation Instrument; BMI: Body mass index; FIGs: Federal Institutes Games; IPAQ: Physical Activity Questionnaire;} PeNSE: Brazilian National School-Based Health Survey; PR: Prevalence ratio PR

\section{Acknowledgements}

The authors would like to thank the Instituto Federal Goiano and the FAPEG Foundation for funding this study.

\section{Authors' contributions}

Matias Noll and Erika Aparecida Silveira conceived and designed the study. Matias Noll and Ana Paula Rodrigues carried out the study. Matias Noll and Erika Aparecida Silveira performed the analysis and wrote the paper. Ana Paula Rodrigues revised the final version. Matias Noll, Ana Paula Rodrigues and Erika Aparecida Silveira approved the final version.

\section{Funding}

The authors are grateful to the FAPEG Foundation for scholarships. The authors are also grateful to the Instituto Federal Goiano for financial fees support.

\section{Availability of data and materials}

The datasets used and/or analyzed during the current study are available from the corresponding author on reasonable request.

\section{Ethics approval and consent to participate}

The present study was in accordance with the Helsinki Declaration and was approved by the Ethics Committee for Human Research of the Instituto Federal Goiano. Athletes and their parents or guardians, in the case of minors, voluntarily signed the informed consent form.
Consent for publication

Not applicable.

\section{Competing interests}

The authors declare that they have no competing interests.

Received: 23 July 2019 Accepted: 29 January 2020

Published online: 12 March 2020

\section{References}

1. Taliaferro LA, Rienzo BA, Donovan KA. Relationships between youth sport participation and selected health risk behaviors from 1999 to 2007. J Sch Health. 2010;80:399-410. https://doi.org/10.1111/j.1746-1561.2010.00520.x.

2. Janssen I, Leblanc A. Systematic review of the health benefits of physical activity and fitness in school-aged children and youth. Sch Nutr Act. 2015: 183-219. https://doi.org/10.1201/b18227-14.

3. Eime RM, Young JA, Harvey JT, Charity MJ, Payne WR. A systematic review of the psychological and social benefits of participation in sport for children and adolescents: informing development of a conceptual model of health through sport. Int J Behav Nutr Phys Act. England. 2013;10:98. https://doi. org/10.1186/1479-5868-10-98.

4. Brasil. Ministério do Esporte [Internet]. 2016 [cited 11 Nov 2016]. Available: http://www.esporte.gov.br/

5. Knapik JJ, Steelman RA, Hoedebecke SS, Austin KG, Farina EK, Lieberman HR. Prevalence of dietary supplement use by athletes: systematic review and meta-analysis. Sports Med. 2016;46:103-23. https://doi.org/10.1007/s40279015-0387-7.

6. Pate RR, Trost SG, Levin S, Dowda M. Sports participation and health-related behaviors among US youth. Arch Pediatr Adolesc Med. 2000;154:904-11.

7. Momaya A, Fawal M, Estes R. Performance-enhancing substances in sports: a review of the literature. Sports Med. 2015;45:517-31. https://doi.org/10. 1007/s40279-015-0308-9.

8. Howie EK, McVeigh JA, Smith AJ, Straker LM. Organized sport trajectories from childhood to adolescence and health associations. Med Sci Sports Exerc. 2016:48:1331-9. https://doi.org/10.1249/MSS.0000000000000894.

9. Scaglioni S, Arrizza C, Vecchi F, Tedeschi S. Determinants of children ' s eating behavior. Am J Clin Nutr. 2011;94:S2006-11. https://doi.org/10.3945/ ajcn.110.001685.1.

10. García-Rovés PM, García-Zapico P, Patterson AM, Iglesias-Gutiérrez E. Nutrient intake and food habits of soccer players: Analyzing the correlates of eating practice. Nutrients. 2014;6:2697-717. https://doi.org/10.3390/ nu6072697.

11. Monteiro CA, Cannon G, Moubarac J-C, Martins APB, Martins CA, Garzillo J, et al. Dietary guidelines to nourish humanity and the planet in the twentyfirst century. A blueprint from Brazil. Public Health Nutr. 2015;18:2311-22. https://doi.org/10.1017/\$1368980015002165.

12. Fardet A, Rock E, Bassama J, Bohuon P, Prabhasankar P, Monteiro C, et al. Current food classifications in epidemiological studies do not enable solid nutritional recommendations for preventing diet-related chronic diseases: the impact of food processing. Adv Nutr. 2015;6:629-38. https://doi.org/10. 3945/an.115.008789.

13. Monteiro CA, Moubarac J-C, Cannon G, Ng SW, Popkin B. Ultra-processed products are becoming dominant in the global food system. Obes Rev. 2013;14:21-8. https://doi.org/10.1111/obr.12107.

14. Moubarac J, Parra DC, Cannon G, Monteiro CA. Food classification systems based on food processing: significance and implications for policies and actions: a systematic literature review and assessment. Curr Obes Rep. 2014; 3:256-72. https://doi.org/10.1007/s13679-014-0092-0.

15. Noll M, de Mendonça CR, de Souza Rosa LP, Silveira EA. Determinants of eating patterns and nutrient intake among adolescent athletes: a systematic review. Nutr J. 2017;16:46. https://doi.org/10.1186/s12937-017-0267-0.

16. Noll M, Rodrigues AP, Silveira EA. Sport types and time spent playing sport are associated with eating pattern among Young Brazilian athletes. Asian J Sports Med. 2019;10:e96561. https://doi.org/10.5812/asjsm.96561.

17. Birkenhead $\mathrm{KL}$, Slater $\mathrm{G}$. A review of factors influencing athletes' food choices. Sports Med. 2015;45:1511-22. https://doi.org/10.1007/s40279-0150372-1.

18. Blondin SA, Anzman-Frasca S, Djang HC, Economos CD. Breakfast consumption and adiposity among children and adolescents: an updated review of the literature. Pediatr Obes. 2016;11:333-48. https://doi.org/10. 1111/ijpo.12082. 
19. Noll M, Silveira EA, de Al. Evaluation of factors associated with severe and frequent back pain in high school athletes. PLoS One. 2017;12:e0171978. https://doi.org/10.1371/journal.pone.0171978.

20. Noll M, de Avelar IS, Lehnen GC, Vieira MF. Back pain prevalence and its associated factors in Brazilian athletes from public high schools: a crosssectional study. PLoS One. 2016;11:e0150542. https://doi.org/10.1371/journal. pone.0150542.

21. Tavares LF, de Castro IRR, Levy RB, Cardoso LO, dos Passos MD, Brito FDSB. Relative validity of dietary indicators from the Brazilian National SchoolBased Health Survey among adolescents in Rio de Janeiro. Brazil Cad Saude Publica. 2014;30:1029-41. https://doi.org/10.1590/0102-311X00000413.

22. Azeredo CM, de Rezende LFM, Canella DS, Claro RM, Peres MFT, Luiz O, Do C, et al. Food environments in schools and in the immediate vicinity are associated with unhealthy food consumption among Brazilian adolescents. Prev Med (Baltim). 2016;88:73-9. https:/doi.org/10.1016/j.ypmed.2016.03.026.

23. Azeredo CM, LFM DR, Canella DS, Moreira Claro R, IRR DC, Luiz O, Do C, et al. Dietary intake of Brazilian adolescents. Public Health Nutr. 2015;18: 1215-24. https://doi.org/10.1017/\$1368980014001463.

24. Mathur C, Stigler M, Lust K, Laska M. A latent class analysis of weight-related health behaviors among 2- and 4-year college students and associated risk of obesity. Health Educ Behav. 2014;41:663-72. https://doi.org/10.1177/ 1090198114537062.

25. Christofaro DGD, De Andrade SM, Mesas AE, Fernandes RA, Farias Júnior JC. Higher screen time is associated with overweight, poor dietary habits and physical inactivity in Brazilian adolescents, mainly among girls. Eur J Sport Sci. 2016;16:498-506. https://doi.org/10.1080/17461391.2015.1068868.

26. Azeredo CM, de Rezende LFM, Mallinson PAC, Ricardo CZ, Kinra S, Levy RB, et al. Progress and setbacks in socioeconomic inequalities in adolescent health-related behaviours in Brazil: results from three cross-sectional surveys 2009-2015. BMJ Open. 2019;9:e025338. https://doi.org/10.1136/bmjopen-2018-025338.

27. Coulthard JD, Palla L, Pot GK. Breakfast consumption and nutrient intakes in 4-18-year-olds: UK National Diet and nutrition survey rolling Programme (2008-2012). Br J Nutr. 2017;118:280-90. https://doi.org/10.1017/ S0007114517001714

28. Matsudo S, Araújo T, Matsudo V, Andrade D, Andrade E, Oliveira LC, et al. Questionário Internacional De Atividade Física (Ipaq): Estupo De Validade E Reprodutibilidade No Brasil. Rev Bras Atividade Física Saúde. 2001;6:5-18. https://doi.org/10.12820/rbafs.v.6n2p5-18.

29. Noll M, Tarragô Candotti C, Vieira A, Fagundes LJ. Back pain and body posture evaluation instrument (BackPEI): development, content validation and reproducibility. Int J Public Health. 2013;58:565-72. https://doi.org/10. 1007/s00038-012-0434-1.

30. Roberts HC, Denison HJ, Martin HJ, Patel HP, Syddall H, Cooper C, et al. A review of the measurement of grip strength in clinical and epidemiological studies: towards a standardised approach. Age Ageing. 2011;40:423-9. https://doi.org/10.1093/ageing/afr051.

31. Prochnik Estima CDC, da Costa RS, Sichieri R, Pereira RA, da Veiga GV. Meal consumption patterns and anthropometric measurements in adolescents from a low socioeconomic neighborhood in the metropolitan area of Rio de Janeiro, Brazil. Appetite. 2009;52:735-9. https://doi.org/10.1016/j.appet. 2009.03.017.

32. Zullig K, Ubbes VA, Pyle J, Valois RF. Self-reported weight perceptions, dieting behavior, and breakfast eating among high school adolescents. J Sch Health. 2006;76:87-92. https://doi.org/10.1111/j.1746-1561.2006.00074.x.

33. Holubcikova J, Kolarcik P, Madarasova Geckova A, van Dijk JP, Reijneveld SA. Lack of parental rule-setting on eating is associated with a wide range of adolescent unhealthy eating behaviour both for boys and girls. BMC Public Health. 2016;16:359. https://doi.org/10.1186/s12889-016-3002-4.

34. Keski-Rahkonen A, Kaprio J, Rissanen A, Virkkunen M, Rose RJ. Breakfast skipping and health-compromising behaviors in adolescents and adults. Eur J Clin Nutr. 2003;57:842-53. https://doi.org/10.1038/sj.ejcn.1601618.

35. Fayet-Moore F, Kim J, Sritharan N, Petocz P. Impact of breakfast skipping and breakfast choice on the nutrient intake and body mass index of Australian children. Nutrients. 2016;8:487. https://doi.org/10.3390/nu8080487.

36. Afeiche MC, Taillie LS, Hopkins S, Eldridge AL, Popkin BM. Breakfast Dietary Patterns among Mexican Children Are Related to Total-Day Diet Quality. J Nutr. 2017:jn239780. https://doi.org/10.3945/jn.116.239780.

37. Tawfik S, El Koofy N, Moawad EMI. Patterns of nutrition and dietary supplements use in young Egyptian athletes: A community-based crosssectional survey. Tauler P, editor. PLoS One. 2016;11: e0161252. doi:https:// doi.org/10.1371/journal.pone.0161252
38. Hull MV, Jagim AR, Oliver JM, Greenwood M, Busteed DR, Jones MT. Gender differences and access to a sports dietitian influence dietary habits of collegiate athletes. J Int Soc Sports Nutr. 2016;13:38. https://doi.org/10.1186/ s12970-016-0149-4.

39. Lazarou C, Matalas A-L. Breakfast intake is associated with nutritional status, Mediterranean diet adherence, serum iron and fasting glucose: the CYFamilies study. Public Health Nutr. 2015;18:1308-16. https://doi.org/10. 1017/\$1368980014001967.

40. Adolphus K, Lawton CL, Champ CL, Dye L. The effects of breakfast and breakfast composition on cognition in children and adolescents: a systematic review. Adv Nutr. 2016;7:590S-612S. https://doi.org/10.3945/an.115.010256.

41. Clayton DJ, Barutcu A, Machin C, Stensel DJ, James LJ. Effect of breakfast omission on energy intake and evening exercise performance. Med Sci Sports Exerc. 2015;47:2645-52. https://doi.org/10.1249/MSS. 0000000000000702

42. Vanelli MC, lovane B, Bernardini A, Chiari G, Errico MK, Gelmetti C, et al. Breakfast habits of 1,202 Northern Italian children admitted to a summer sport school. Breakfast skipping is associated with overweight and obesity. Acta Biomed l'Ateneo Parm. 2005;76:79-127 Available: https://www.scopus. com/inward/record.uri?eid=2-s2.0-31944445330\&partnerlD=40\&md5= 60d823dc517df335ae6e8ba9222c32e0.

43. Fortes L de S, Kakeshita IS, Almeida SS, Gomes AR, MEC F. Eating behaviours in youths: A comparison between female and male athletes and nonathletes. Scand J Med Sci Sports. 2014;24:e62-8. https://doi.org/10.1111/sms. 12098 Denmark.

44. Parks RB, Helwig D, Dettmann J, Taggart T, Woodruff B, Horsfall K, et al. Developing a performance nutrition curriculum for collegiate athletics. J Nutr Educ Behav. 2016. https://doi.org/10.1016/j.jneb.2016.03.002.

45. Pisarek A, Guszkowska M, Zagórska A, Lenartowicz M. Characteristics of athletes' approach to the question of physical health and health behaviors: do athletes Lead healthy lifestyles? J Appl Sport Psychol. 2011;23:459-73. https://doi.org/10.1080/10413200.2011.594851.

46. Dalky HF, Al Momani MH, Al-Drabaah TK, Jarrah S. Eating habits and associated factors among adolescent students in Jordan. Clin Nurs Res. 2016. https://doi.org/10.1177/1054773816646308.

47. Voráčová J, Sigmund E, Sigmundová D, Kalman M. Changes in eating behaviours among Czech children and adolescents from 2002 to 2014 (HBSC study). Int J Environ Res Public Health. 2015;12:15888-99. https://doi. org/10.3390/ijerph121215028.

48. Coutinho LAA, Porto CPM, Pierucci APTR. Critical evaluation of food intake and energy balance in young modern pentathlon athletes: a cross-sectional study. J Int Soc Sports Nutr. 2016;13:15. https://doi.org/10.1186/s12970-016-0127-x.

49. Baumert PW, Henderson JM, Thompson NJ. Health risk behaviors of adolescent participants in organized sports. J Adolesc Health. 1998;22:460-5. https://doi.org/10.1016/S1054-139X(97)00242-5.

50. Kamphuis CBM, Giskes K, de Bruijn GJ, Wendel-Vos W, Brug J, van Lenthe FJ. Environmental determinants of fruit and vegetable consumption among adults: a systematic review. Br J Nutr. 2006;96:620-35. https://doi.org/10. 1079/bjn20061896.

51. Ness AR, Powles JW. Fruit and vegetables, and cardiovascular disease: a review. Int J Epidemiol. 1997;26:1-13.

52. Block G, Patterson B, Subar A. Fruit, vegetables, and cancer prevention: a review of the epidemiological evidence. Nutr Cancer. 1992;18:1-29. https:// doi.org/10.1080/01635589209514201.

53. Nguyen B, Bauman A, Gale J, Banks E, Kritharides L, Ding D. Fruit and vegetable consumption and all-cause mortality: evidence from a large Australian cohort study. Int J Behav Nutr Phys Act. 2016;13:9. https://doi.org/ 10.1186/s12966-016-0334-5.

54. Pesa JA, Turner LW. Fruit and vegetable intake and weight-control behaviors among US youth. Am J Health Behav. 2001;25:3-9. https://doi. org/10.5993/AJHB.25.1.1.

55. Johnson RK. Reducing intake of sugar-sweetened beverages is vital to improving our Nation's health: table. Circulation. 2016;133:347-9. https://doi. org/10.1161/CIRCULATIONAHA.115.020453.

56. Ma J, McKeown NM, Hwang S-J, Hoffmann U, Jacques PF, Fox CS. Sugarsweetened beverage consumption is associated with change of visceral adipose tissue over 6 years of follow-up. Circulation. 2016;133:370-7. https:// doi.org/10.1161/CIRCULATIONAHA.115.018704.

57. Rippe JM, Angelopoulos TJ. Sugars and health controversies: what does the science say? Adv Nutr An Int Rev J. 2015;6:493S-503S. https://doi.org/10. 3945/an.114.007195. 
58. Malik VS, Popkin BM, Bray GA, Després J-P, Hu FB. Sugar-sweetened beverages, obesity, type 2 diabetes mellitus, and cardiovascular disease risk. Circulation. 2010;121:1356-64. https://doi.org/10.1161/CIRCULATIONAHA.109.876185.

59. Zheng Y, Ley SH, Hu FB. Global aetiology and epidemiology of type 2 diabetes mellitus and its complications. Nat Rev Endocrinol. 2018;14:88-98. https://doi.org/10.1038/nrendo.2017.151.

60. Fiolet T, Srour B, Sellem L, Kesse-Guyot E, Allès B, Méjean C, et al. Consumption of ultra-processed foods and cancer risk: results from NutriNet-Santé prospective cohort. BMJ. 2018;k322. https://doi.org/10.1136/bmj.k322.

61. Costa CS, Del-Ponte B, Assunção MCF, Santos IS. Consumption of ultraprocessed foods and body fat during childhood and adolescence: a systematic review. Public Health Nutr. 2018;21:148-59. https://doi.org/10. 1017/S1368980017001331.

62. da Costa Louzada ML, Martins APB, Canella DS, Baraldi LG, Levy RB, Claro RM, et al. Ultra-processed foods and the nutritional dietary profile in Brazil. Rev Saude Publica. 2015;49:38. https://doi.org/10.1590/S0034-8910. 2015049006132

63. Brasil. Ministry of Health of Brazil. Primary Health Care Department dietary guidelines for the Brazilian population. Brasilia: Ministério da Saúde; 2014. https://bvsms.saude.gov.br/bvs/publicacoes/guia_alimentar_populacao_ brasileira_2ed.pdf.

64. Sleddens EFC, Kroeze W, Kohl LFM, Bolten LM, Velema E, Kaspers P, et al. Correlates of dietary behavior in adults: an umbrella review. Nutr Rev. 2015; 73:477-99. https://doi.org/10.1093/nutrit/nuv007.

65. Pearson N, Biddle SJH. Sedentary behavior and dietary intake in children, adolescents, and adults. Am J Prev Med. 2011;41:178-88. https://doi.org/10. 1016/j.amepre.2011.05.002.

66. Robinson TN, Banda JA, Hale L, Lu AS, Fleming-Milici F, Calvert SL, et al. Screen media exposure and obesity in children and adolescents. Pediatrics. 2017;140:S97-S101. https://doi.org/10.1542/peds.2016-1758K.

67. Rezende LFM de, Rodrigues Lopes M, Rey-López JP, Matsudo VKR, Luiz O do C. Sedentary Behavior and Health Outcomes: An Overview of Systematic Reviews. Lucia A, editor. PLoS One. 2014;9: e105620. doi:https://doi.org/10. 1371/journal.pone.0105620

68. Gubbels JS, van Assema P, Kremers SPJ. Physical activity, sedentary behavior, and dietary patterns among children. Curr Nutr Rep. 2013;2:105-12. https:// doi.org/10.1007/s13668-013-0042-6

69. Martens MP, Dams-O'Connor K, Beck NC. A systematic review of college student-athlete drinking: prevalence rates, sport-related factors, and interventions. J Subst Abus Treat. 2006;31:305-16. https://doi.org/10.1016/j. jsat.2006.05.004

70. Lisha NE, Crano WD, Delucchi KL. Participation in team sports and alcohol and marijuana use initiation trajectories. J Drug Issues. 2013;44:83-93. https://doi.org/10.1177/0022042613491107.

\section{Publisher's Note}

Springer Nature remains neutral with regard to jurisdictional claims in published maps and institutional affiliations.

Ready to submit your research? Choose BMC and benefit from:

- fast, convenient online submission

- thorough peer review by experienced researchers in your field

- rapid publication on acceptance

- support for research data, including large and complex data types

- gold Open Access which fosters wider collaboration and increased citations

- maximum visibility for your research: over $100 \mathrm{M}$ website views per year

At BMC, research is always in progress.

Learn more biomedcentral.com/submissions 